\title{
Sinterability of $\mathrm{TiB}_{2}$ Ceramics Containing $\mathrm{Cr}$ and $\mathrm{C}$ as the Sintering Aids
}

\author{
Junichi MATSUSHITA and Akira SANO \\ Toshiba Ceramics Co., Ltd., 1, Minamifuji, Ogakie-cho, Kariya-shi \\ 448
$\mathrm{Cr}$ と C を焼結助剤として添加した $\mathrm{TiB}_{2}$ セラミックスの焼結性
松下純一・佐野 省 \\ 東芝セラミックス(株) $\mathrm{FC}$ 事業推進部技術部, 448 愛知県刈谷市小垣江町南藤 1 番地
}

[Received November 12, 1991; Accepted February 18, 1992]

\begin{abstract}
The effect of $\mathrm{Cr}$ and $\mathrm{C}$ addition on the sintering process of $\mathrm{TiB}_{2}$ ceramics was investigated and discussed from microstructural and compositional viewpoints. Simultaneous addition of $6.2 \mathrm{wt} \% \mathrm{Cr}$ and $1.3 \mathrm{wt} \% \mathrm{C}$ resulted in high density, high bending strength and high hardness. Results of $\mathrm{X}$-ray diffraction of the $\mathrm{TiB}_{2}$ composite fired at $900^{\circ}-1900^{\circ} \mathrm{C}$ showed that $\mathrm{Cr}$ and $\mathrm{C}$ reacted with $\mathrm{TiB}_{2}$ to form $\mathrm{CrB}$ and $\mathrm{TiC}$ during the sintering process.
\end{abstract}

Key-words : $\mathrm{TiB}_{2}$, Pressureless sintering, Sinterability, Densification, Solid solution, Microstructure

\section{Introduction}

Titanium boride $\left(\mathrm{TiB}_{2}\right)$ has various desirable properties, such as high melting point $\left(2980^{\circ} \mathrm{C}\right)$, high hardness (32 $\mathrm{GPa})$, and moderate electrical conductivity $\left(10^{-5} \Omega \cdot \mathrm{cm}\right)$. $\mathrm{TiB}_{2}$ has potential uses for wear resistant materials, electrodes for aluminum electrolysis, cathode of $\mathrm{CO}_{2}$ reduction and parts for vapor deposition.

One of its major disadvantages, however, is poor sinterability, and many attempts are being made to overcome the disadvantage, including hot pressing with sintering aids, ${ }^{1), 2)}$ sintering of ultrafine $\mathrm{TiB}_{2}$ powder synthesized by the arc plasma process without a sintering aid, ${ }^{3), 4}$ and combination with $\mathrm{Al}_{2}$ $\mathrm{O}_{3}, \mathrm{ZrO}_{2}, \mathrm{SiC}$ or $\mathrm{Ti}(\mathrm{C}, \mathrm{N})$ to form $\mathrm{TiB}_{2}$ composite materials. ${ }^{5)-9)}$

The authors attempted to produce a highly density $\mathrm{TiB}_{2}$ sintered body by pressureless sintering, and found that $\mathrm{TiB}_{2}$ could be high densified in the presence of both $\mathrm{Cr}$ and C. ${ }^{10), 11)}$ However, the function of $\mathrm{Cr}$ and $\mathrm{C}$ in the densification process of the $\mathrm{TiB}_{2}$ composite containing $\mathrm{Cr}$ and $\mathrm{C}$ had not been clarified. In this study, the effect of $\mathrm{Cr}$ and $\mathrm{C}$ on the sinterability of $\mathrm{TiB}_{2}$ was investigated.

\section{Experimental procedure}

Properties of $\mathrm{TiB}_{2}$ (Cerac Co.), Cr (Soegawa Rikagaku Co.) and C (Mitsubishi Kasei Co.) powders are shown in Table 1. Their average particle sizes and purities are catalogue values, whereas the impurity contents were determined by inductivelycoupled plasma emission spectroscopy. The oxygen and carbon contents in the $\mathrm{TiB}_{2}$ powder was measured using an oxygen and carbon analyzer(Leco
Co.) and the result is given in Table 2 .

The powders were blended in the specified ratio and mixed in ethyl alcohol for $24 \mathrm{~h}$ using a plastic ontainer and nylon balls. After drying, the mixture was die-pressed with a pressure of $30 \mathrm{MPa}$, and subsequently formed into a bar shape (about $10 \mathrm{~mm} \times 10$ $\mathrm{mm} \times 50 \mathrm{~mm}$ in size) by CIP at $300 \mathrm{MPa}$. The green bodies were packed in a carbon container, and sintered in an electric furnace with carbon heater at $1900^{\circ} \mathrm{C}$ for $1 \mathrm{~h}$ under an argon atmosphere. The heating rate was $15^{\circ} \mathrm{C} / \mathrm{min}$. After sintering, the sintered bodies were furnace-cooled under argon.

The density of the sintered body was measured by the Archimedean method.

The sintered body was cut into $4 \mathrm{~mm} \times 3 \mathrm{~mm} \times 40$ $\mathrm{mm}$ bars and polished with a diamond disc to prepare the samples for the 4-point bending test. The measurement was repeated 5 times for each data point, under the conditions of upper span: $10 \mathrm{~mm}$, lower span: $30 \mathrm{~mm}$ and crosshead speed: $0.5 \mathrm{~mm} /$ min.

The Vickers hardness was measured under the conditions of load: $98 \mathrm{~N}$ and time: $20 \mathrm{~s}$.

The crystalline phases in the specimens fired at $900^{\circ} \mathrm{C}$ to $1900^{\circ} \mathrm{C} \times 1$ min were identified by powder $\mathrm{X}$-ray diffraction analysis.

Table 1. Average particle size and chemical composition of raw materials.

\begin{tabular}{cccc}
\hline Material & $\begin{array}{c}\text { Average particle } \\
\text { size }(\mu \text { m })\end{array}$ & Purity $(\boldsymbol{x})$ & Impurity $(\boldsymbol{x})$ \\
\hline $\mathrm{TiB}_{2}$ & 2.65 & 99 & $\begin{array}{l}\mathrm{Si}: 0.3, \mathrm{Mg}: 0.3, \mathrm{Fe}: 0.2 \\
\mathrm{Al}: 0.1, \mathrm{Ca}: 0.01, \mathrm{Cr}: 0.001\end{array}$ \\
$\mathrm{Cr}$ & 3.0 & 99 & $\begin{array}{l}\mathrm{Fe}: 0.3, \mathrm{~S}: 0.03, \mathrm{C}: 0.02 \\
\mathrm{Al}: 0.01, \mathrm{Si}: 0.01\end{array}$ \\
$\mathrm{C}$ & 0.03 & 99.9 & $\begin{array}{l}\mathrm{Na}: 0.01, \mathrm{Ca}: 0.01, \mathrm{Fe}: 0.003 \\
\mathrm{Al}: 0.001, \mathrm{Mg}: 0.001, \mathrm{Si}: 0.001\end{array}$ \\
\hline
\end{tabular}

Table 2. Total oxygen and carbon contents of raw materials.

\begin{tabular}{|c|c|c|c|}
\hline Material & Total & oxygen (wtz) & Total carbon (wt $z$ ) \\
\hline $\mathrm{TiB}_{2}$ & & 0.9 & 0.6 \\
\hline $\mathrm{Cr}$ & & 0.6 & 0.0 \\
\hline C & & 0.2 & - \\
\hline
\end{tabular}




\section{Results and discussion}

The combinations of $\mathrm{Cr}$ and $\mathrm{C}$ increased sintered density significantly over that of the sintered bodies containing $\mathrm{Cr}$ alone, indicating that the sintering of $\mathrm{TiB}_{2}$ was greatly accelerated in the presence of both $\mathrm{Cr}$ and $\mathrm{C}$. A total aid quantity of $7.5 \mathrm{wt} \%(\mathrm{Cr} / \mathrm{C}$ ratio: $7 / 1.5$, weight: $6.2 \mathrm{wt} \% \mathrm{Cr}-1.3 \mathrm{wt} \% \mathrm{C}$ ) gave a relative density as high as $\left.98 \% .{ }^{10)}, 11\right)$

Table 3 shows the mechanical properties of $\mathrm{TiB}_{2}$, $\mathrm{TiB}_{2}$ containing $7.5 \mathrm{wt} \% \mathrm{Cr}$ and $\mathrm{TiB}_{2}$ composite containing $7.5 \mathrm{wt} \%$ of $\mathrm{Cr}$ and $\mathrm{C}(\mathrm{Cr} / \mathrm{C}: 7 / 1.5)$, respectively, sintered at $1900^{\circ} \mathrm{C}$ for $1 \mathrm{~h}$.

The improved mechanical properties resulted conceivably from the increased density.

The $\mathrm{TiB}_{2}$ compacts containing $6.2 \mathrm{wt} \% \mathrm{Cr}$ and 1.3 wt $\% \mathrm{C}$ were fired at $900^{\circ} \mathrm{C}$ to $1900^{\circ} \mathrm{C}$ for $1 \mathrm{~min}$. The crystalline phases of $\mathrm{TiB}_{2}$ composites were determined by powder $\mathrm{X}$-ray diffraction, as given in Table 4. In the sample fired at $1100^{\circ} \mathrm{C}$, the diffraction peaks for $\mathrm{TiB}_{2}$ and $\mathrm{Cr}_{3} \mathrm{C}_{2}$ were detected. In the sample fired at $1300^{\circ} \mathrm{C}$, the diffraction peaks for $\mathrm{Cr}_{3}$ $\mathrm{C}_{2}$ disappeared, and those for $\mathrm{CrB}$ and $\mathrm{TiC}$, although broad, appeared, in addition to those for $\mathrm{TiB}_{2}$. In the sample fired at $1700^{\circ} \mathrm{C}$ or higher, sharp diffraction peaks for $\mathrm{CrB}$ and $\mathrm{TiC}$ were found, in addition to those for $\mathrm{TiB}_{2}$.

Figure 1 shows the shrinkage curve of the sample containing $\mathrm{Cr}$ and $\mathrm{C}$, in which the sintering-induced

Table 3. Mechanical properties of the $\mathrm{TiB}_{2}$ composites.

Specimens were fabricated by pressureless sintering at $1900^{\circ} \mathrm{C}$ for $1 \mathrm{~h}$ in argon gas.

\begin{tabular}{|c|c|c|c|}
\hline Composition (wtx) & $T i B_{2}$ 100x & Ti $B_{2}-7.5 x \mathrm{Cr}$ & $T i B_{2}-6.2 x \mathrm{Cr}-1.3 \times \mathrm{C}$ \\
\hline Relative density (x) & 78 & 91 & 99 \\
\hline Bending strength (MPa) & 160 & 308 & 405 \\
\hline Vickers hardness (GPa) & 3 & 15 & 23 \\
\hline
\end{tabular}

Table 4. Crystalline phases of $\mathrm{TiB}_{2}-6.2 \mathrm{wt} \% \mathrm{Cr}-1.3 \mathrm{wt} \% \mathrm{C}$ raw material and the composite fired at $900^{\circ} \mathrm{C}$ to $1900^{\circ} \mathrm{C}$.

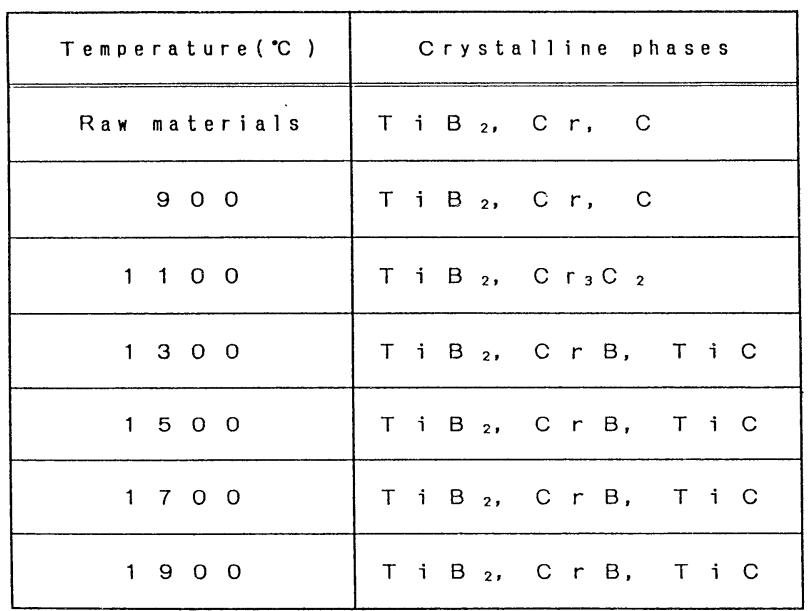

shrinkage started between $1100^{\circ}$ and $1300^{\circ} \mathrm{C}$. No $\mathrm{Cr}_{3}$ $\mathrm{C}_{2}$ peak was detected, but the peaks of $\mathrm{TiB}_{2}, \mathrm{CrB}$ and $\mathrm{TiC}$ were detected by $\mathrm{X}$-ray diffraction in the specimens sintered at $1300^{\circ} \mathrm{C}$ or higher.

The above results suggest that the following reactions took place during the sintering process:

$$
\begin{aligned}
& \mathrm{TiB}_{2}+\mathrm{Cr}+\mathrm{C} \stackrel{\approx 1100^{\circ} \mathrm{C}}{\longrightarrow} \mathrm{TiB}_{2}+\mathrm{Cr}_{3} \mathrm{C}_{2} \\
& \mathrm{TiB}_{2}+\mathrm{Cr}_{3} \mathrm{C}_{2} \stackrel{>1300^{\circ} \mathrm{C}}{\longrightarrow} \mathrm{TiB}_{2}+\mathrm{CrB}+\mathrm{TiC}
\end{aligned}
$$

Figure 2 shows $\mathrm{X}$-ray diffraction peaks for $\mathrm{TiB}_{2}$ (201) plane. It is seen that the diffraction peaks in the sintered body of $\mathrm{TiB}_{2}$ added with $\mathrm{Cr}$ and $\mathrm{C}$ shifted towards higher angles from the positions for the

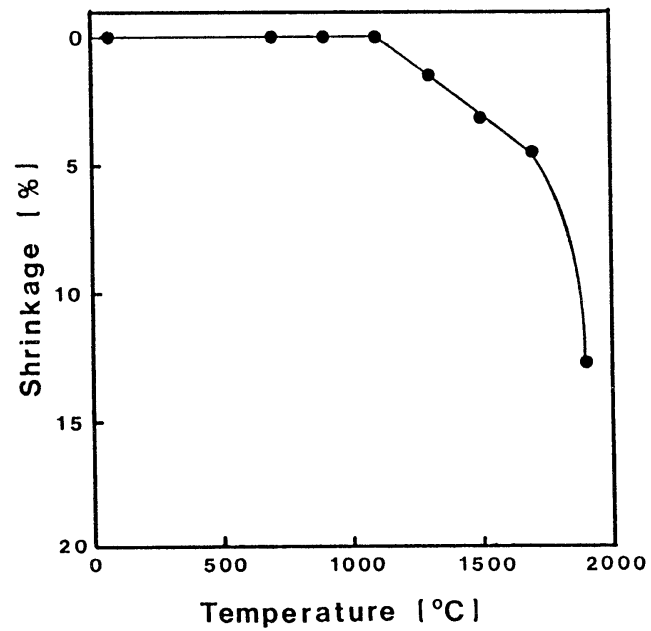

Fig. 1. Linear shrinkage curve of $\mathrm{TiB}_{2}-6.2 \mathrm{wt} \% \mathrm{Cr}-1.3 \mathrm{wt} \% \mathrm{C}$ specimen.

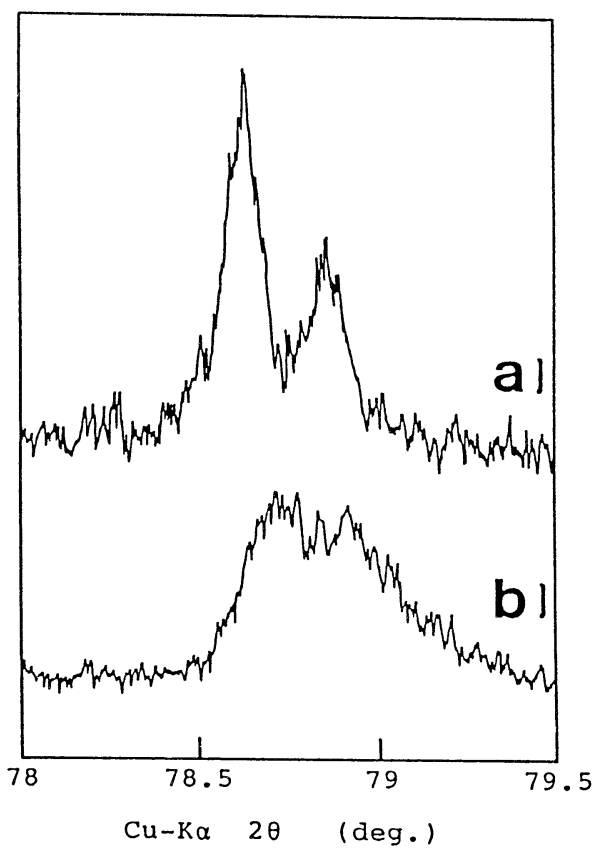

Fig. 2. X-ray diffraction patterns of $\mathrm{TiB}_{2}(201)$.

(a) $\mathrm{TiB}_{2}-6.2 \mathrm{wt} \% \mathrm{Cr}-1.3 \mathrm{wt} \% \mathrm{C}$ raw material.

(b) $\mathrm{TiB}_{2}-6.2 \mathrm{wt} \% \mathrm{Cr}-1.3 \mathrm{wt} \% \mathrm{C}$ composite sintered at $1900^{\circ} \mathrm{C}$ for $1 \mathrm{~h}$. 
$\mathrm{TiB}_{2}$ starting powder. We assume that the unit lattice of the $\mathrm{TiB}_{2}$ crystal in the specimen contracted due to the solid solution, so that the diffraction peaks for $\mathrm{TiB}_{2}$ shifted towards higher angles.

It is also considered that oxygen $(0.9 \mathrm{wt} \%)$ and carbon $(0.6 \mathrm{wt} \%)$ present in the starting powder as impurities (Table 2) affected the sinterability of $\mathrm{TiB}_{2}$. In particular, the amount of oxygen considered to be present on the starting particle surfaces was decreased by reaction with the carbon present as the impurity and the newly added aid to form CO gas. ${ }^{12)}$

It is considered, based on these results, that $\mathrm{Cr}$ and $\mathrm{C}$ added to $\mathrm{TiB}_{2}$ reacted to form phases of $\mathrm{CrB}$ and $\mathrm{TiC}$ during the sintering process, which promoted the bonding between $\mathrm{TiB}_{2}$ grains, removed pores and contributed greatly to densification of the sintered bodies.

Therefore, a sintered body of $\mathrm{TiB}_{2}$ having increased density, high strength and high hardness can be obtained by the addition of $\mathrm{Cr}$ and $\mathrm{C}$ to $\mathrm{TiB}_{2}$.

\section{Conclusions}

$\mathrm{TiB}_{2}$ ceramics was sintered pressurelessly in the simultaneous presence of $\mathrm{Cr}$ and $\mathrm{C}$, in order to investigate the effects of these sintering aids on the sinterability of the $\mathrm{TiB}_{2}$ composites.

Simultaneous addition of $\mathrm{Cr}$ and $\mathrm{C}$ as the sintering aids accelerated the densification of $\mathrm{TiB}_{2}$ significantly.

It is considered that the addition of both $\mathrm{Cr}$ and $\mathrm{C}$ was effective in promoting the bonding between grains and removing pores to achieve high density.
Thus, a sintered body of $\mathrm{TiB}_{2}$ having increased density, high strength and high hardness can be obtained by the addition of $\mathrm{Cr}$ and $\mathrm{C}$ to $\mathrm{TiB}_{2}$.

Acknowledgment The authors sincerely thank Prof., Dr. Hajime Saito, Toyota Technological Institute for his valuable suggestion and advice in this study.

\section{References}

1) V. J. Tennery, C. B. Finch, C. S. Yust and G. W. Clark, "Science of Hard Materials", Plenum Press Pub. Co. (1981) pp. 891-909.

2) T. Watanabe and S. Kuno, Am. Ceram. Soc. Bull., 61, 97073 (1987).

3) H. R. Baumgartner and R. A. Steiger, J. Am. Ceram. Soc., 67, 207-11 (1984).

4) H. R. Baumgartner, J. Am. Ceram. Soc., 67, 490-97 (1984).

5) K. Shobu, T. Watanabe and H. Yamamoto, Yogyo-KyokaiShi (J. Ceram. Soc. Japan), 93, 252-56 (1985).

6) J. Matsushita, S. Hayashi and H. Saito, Seramikkusu Ronbunshi (J. Ceram. Soc. Japan), 97, 1206-10 (1989).

7) J. Matsushita, H. Nagashima and H. Saito, J. Jpn. Soc. Powder and Powder Metallurgy, 37, 551-55 (1990).

8) I. Kimura, Y. Hiraoka, N. Hotta and S. Matsuo, 1985 Symposium Proceedings of Tohoku/Hokkaido Division, The Ceramic Society of Japan (1985) pp. 41-42.

9) C. C. Sorrell, V. S. Stubican and R. C. Bradt, J. Am. Ceram. Soc., 69, 317-21 (1986).

10) S. Hayashi, H. Saito, J. Matsushita and H. Nagashima, Proceedings of Sintering '87, Elsevier Applied Science (1988) pp. 1302-07.

11) J. Matsushita, H. Nagashima, S. Hayashi and H. Saito, Proceedings of the 27th Ceramic Basic Seminar of the Ceramic Society of Japan (1989) p. 29.

12) S. Baik and P. F. Beacher, J. Am. Ceram. Soc., 70, 527-30 (1987). 